\title{
Hydrogen Evolution in Seeds of Nelumbo nucifera and Other Angiosperms
}

\author{
by Kiyonobu TOYODA*
}

Received July 18, 1966

\begin{abstract}
Hydrogen evolution in homogenates of germinated seeds of Nelumbo nucifera and some other angiosperms were investigated.

The rate of hydrogen evolution was very high for first 1 to 2 days, and decreased rapidly. Its rate was suppressed by air, indicating the participation of hydrogenase in the mechanism. The optimum $\mathrm{pH}$ for the hydrogen evolution in Nelumbo cotyledon homogenate was about 7.2.
\end{abstract}

In a various paper ${ }^{1)}$, it has been shown that $\mathrm{CO}_{2}$-content in the gas liberated from Nelumbo seeds under anaerobic conditions was about $90 \%$, while in the gas from their homogenates $\mathrm{CO}_{2}$-content was only $22.5 \%$. The present experiment was undertaken to examine what is the main component of the gas from the homogenates. It was found that this gas was combustible and was adsorbed on palladium asbestos. We concluded that more than 30 percent of the gas consisted of hydrogen. Small amount of molecular hydrogen was also detected when germinated seeds of Nelumbo were incubated under anaerobic conditions either in the dark or in the light. The evolution of hydrogen was further demonstrated with seeds of some other angiosperms.

It is known that, under certain conditions, photosynthetic bacteria ${ }^{2-4}$, Scenedes$m u s^{5,6)}$, Chlamydomonas ${ }^{7,8)}$, Chlorella $a^{9-14)}$ and certain strains of marine algae ${ }^{15)}$ can produce hydrogen. The participation of hydrogenase ${ }^{16,17)}$ in the mechanism is generally accepted. However, no report on hydrogen evolution from plant seeds nor on existence of hydrogenase in higher plants appeared so far. We will report here the results of experiment which clearly demonstrated the evolution of hydrogen in homogenates of seeds of Nelumbo and other higher plants.

\section{Materials and Methods}

Seeds of Nelumbo nucifera Gaertn. were mainly used. Seeds of Oryza sativa, Glycine Max and Pheseolus valgaris were supplementally employed.

Nelumbo fruits were cut at both ends and soaked in water. After four days, the plumule extended $1-5 \mathrm{~mm}$ from the fruit-coat. The fruit-coats were peeled off. Three seeds were placed in a large syringes $(30 \mathrm{ml})$ and were washed with $0.5 \%$ usupulun solution, distilled water, and finally with phosphate buffer (M/15, pH 7.0). Dry weight of three Nelumbo seeds was about $2 \mathrm{~g}$. Homogenates were prepared from three Nelumbo seeds by grinding in a glass-motar with phosphate buffer and introduced into large syringes. The opening end of the syringe was fitted with a rubber cap. The volume of reaction mixture was $20 \mathrm{~m} l$. To get rid of bacterial contamina-

\footnotetext{
* Biological Laboratory, Kanagawa Dental College, Inaoka-cho, Yokosuka, Japan.
} 
tion, all procedures were carried out under asepitc conditions. After definite times of incubation, the evolved gas was transferred into another syringe and carbon dioxide was absorbed with $20 \% \mathrm{KOH}$. The volume of residual gas was measured at $25^{\circ}$. The residual gas finally transferred into a inverted graduated test tube placed in the vessel filled with water. Air of about $5 / 2$ of the gas was introduced. An igniter which was made of nichrome wire, a dry cell and electric wire was inserted into the test tube. The contents were lighted and detonated, and the decrease in gas volume was measured at $25^{\circ}$. No change in the volume occured by treatment with $20 \% \mathrm{KOH}$. The amount of hydrogen estimated by the equation : $2 \mathrm{H}_{2}+\mathrm{O}_{2} \rightarrow 2 \mathrm{H}_{2} \mathrm{O}$. The average of three or more measurements was teken. The amount of hydrogen estimated in this way agreed within experimental error with that estimated by palladium asbestos adsorption method.

Experiments with seeds of Oryza sativa, Glycine Max and Phaseolus vulgaris were carried out in a similar way. About $3 \mathrm{~g}$ of the samples were used in each run.

\section{Results}

Table 1 shows the evolution of hydrogen in intact seeds of Nelumbo and other plants, and their homogenates. In the intact seeds, the rate of gas evolution was estimated from the amounts of gases evolved for 3 days.

The amount of hydrogen evolved and its percentage in the evolved gas were markedly large in the homogenates than in the intact seeds.

Germinated Nelumbo seeds were separated into cotyledons, and plumules with small portion of the cotyledons on their bases. Nine plumules and six cotyledons were put into the seyringes. Table 2 summarizes the results of experiment in which hydrogen evolution in cotyledons and plumules of Nelumbo seeds was measured separately. The amount of total gas was small in plumule but the rate of hydrogen

Table 1. Hydrogen evolution under anaerobic conditions in seeds of Nelumbo and of other angiosperms, and in their homogenates.*

\begin{tabular}{|c|c|c|c|c|}
\hline Materials & $\begin{array}{c}\text { Total gas } \\
\text { evolved }(\mathrm{m} l)\end{array}$ & $\begin{array}{l}\text { Gas remaining } \\
\text { after treatment with } \\
20 \% \mathrm{KOH}(\mathrm{ml})\end{array}$ & Hydrogen $(\mathrm{m} l)$ & $\begin{array}{l}\text { Percentage of } \\
\mathrm{H}_{2} \text { in total gas }\end{array}$ \\
\hline \multicolumn{5}{|c|}{ Nelumbo nucifera } \\
\hline Intact seeds & 7.8 & 0.7 & 0.1 & 1.3 \\
\hline Homogenates & 22.0 & 10.5 & 8.3 & 37.7 \\
\hline \multicolumn{5}{|l|}{ Oryza sativa } \\
\hline Intact seeds & 6.8 & 0.8 & 0.2 & 3.0 \\
\hline Homogenates & 9.5 & 3.5 & 2.9 & 30.5 \\
\hline \multicolumn{5}{|l|}{ Glycine Max } \\
\hline Intact seeds & 4.5 & 0.8 & 0.2 & 4.4 \\
\hline Homogenates & 5.0 & 1.2 & 0.8 & 16.0 \\
\hline \multicolumn{5}{|c|}{ Phaseolus vulgaris } \\
\hline Intact seeds & 5.5 & 0.8 & 0.1 & 1.8 \\
\hline Homogenates & 3.2 & 1.8 & 1.4 & 43.8 \\
\hline
\end{tabular}

* Phosphate buffer, $\mathrm{M} / 15$, pH 7.0 ; figures refer to volume of gases evolved during 24 hours and measured at $25^{\circ}$. 


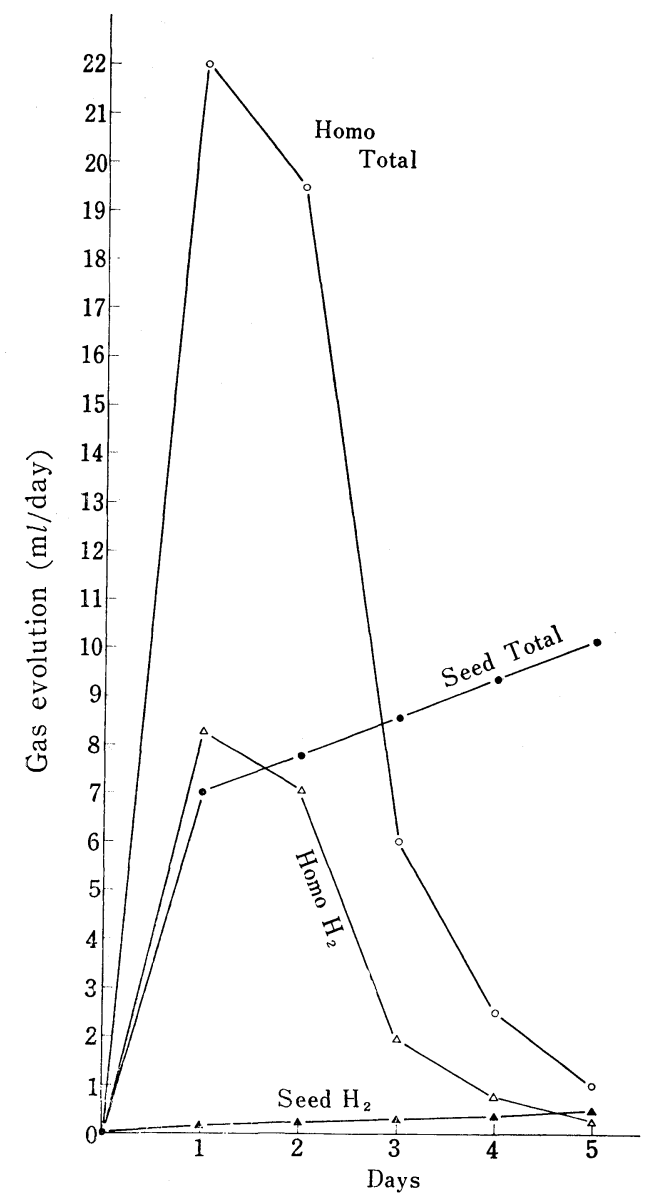

Fig. 1. Gas evolution by Nelumbo seed and its homogenate at $25^{\circ}$.

Abbreviations: Homo, homogenate; Total, total gas volume.

evolution comparatively high. In cotyledons, the data did not differ so much from those in the seeds.

Time courses of the evolution of total gas and of hydrogen in the Nelumbo seeds and their homogenates are shown in Fig. 1. The amounts of gases evolved were measured at 24 hours intervals. The rate of gas evolution in the homogenates was very high at first and then decreased rapidly. More than thirty percent of the gas was occupied by $\mathrm{H}_{2}$. On the other hand, the rate of gas evolution in the intact seeds remained

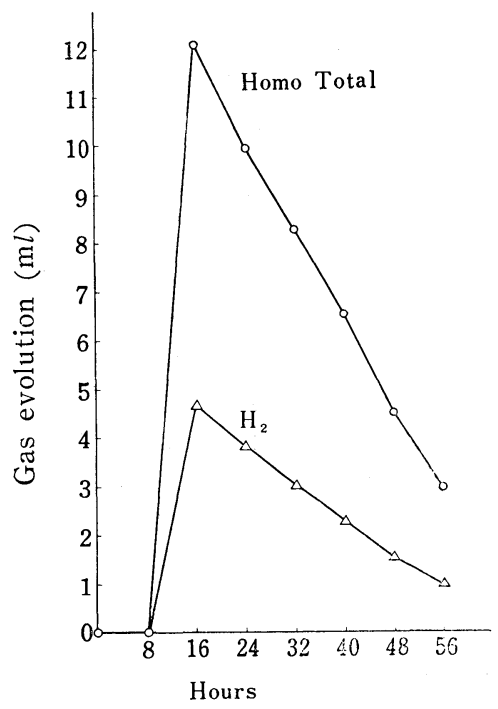

Fig. 2. Gas evolution in Nelumbo seed homogenate which was measured at intervals of 8 hours.

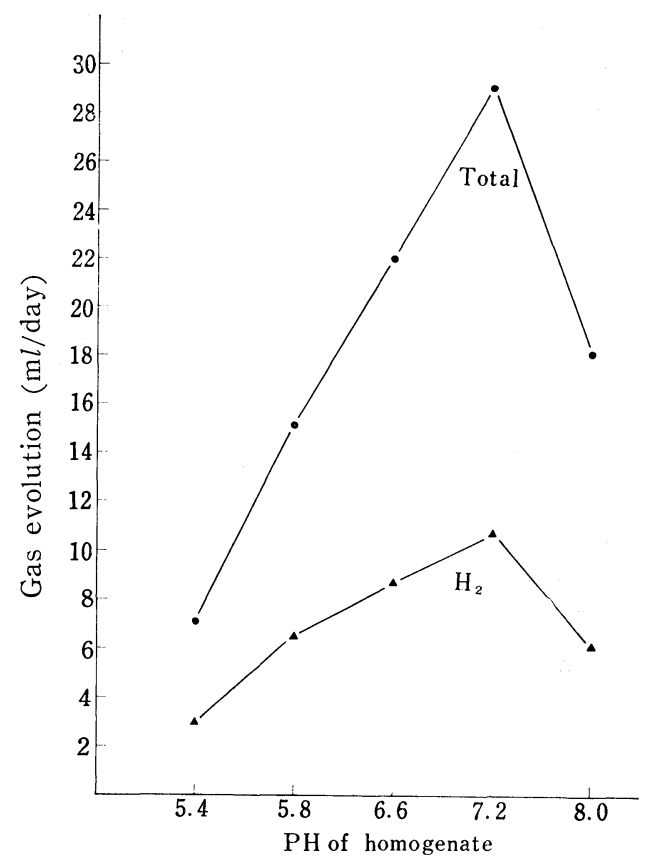

Fig. 3. Gas evolution in homogenates of Nelumbo cotyledons under various $\mathrm{pH}$ conditions. 
Table 2. Hydrogen evolution in plumules and cotyledons of Nelumbo at $25^{\circ}$ for 24 hours.

\begin{tabular}{lcccc}
\hline Materials & $\begin{array}{c}\text { Total gas } \\
\text { evolved }(\mathrm{m} l)\end{array}$ & $\begin{array}{c}\text { Gas remaining } \\
\text { after treatment } \\
\text { with KOH }(\mathrm{m} l)\end{array}$ & Hydrogen $(\mathrm{m} l)$ & $\begin{array}{c}\text { Percentage of } \\
\mathrm{H}_{2} \text { in total gas }\end{array}$ \\
\hline Plumules* & 2.6 & 0.5 & 0.2 & 7.7 \\
Cotyledons** & 8.0 & 0.4 & 0.1 & 1.2 \\
\hline
\end{tabular}

* Fresh weight is $0.63 \mathrm{~g}, * * 2.3 \mathrm{~g}$.

Table 3. Effect of air on hydrogen evolution in the cotyledon homogenates of Nelumbo seed.

\begin{tabular}{lccc}
\hline \multicolumn{1}{c}{ Time } & $\begin{array}{c}\text { Total gas } \\
\text { evolved }(\mathrm{m} l)\end{array}$ & Hydrogen $(\mathrm{m} l)$ & $\begin{array}{c}\text { Percentage of } \\
\mathrm{H}_{2} \text { in total gas }\end{array}$ \\
\hline First 24 hours & 15.0 & 3.7 & 24.6 \\
Second 24 hours & 23.0 & 6.5 & 28.3 \\
Third 24 hours & 5.5 & 1.2 & 21.8 \\
$\quad$ Control (without air) & & & \\
First 24 hours & 22.1 & 8.1 & 36.7 \\
Second 24 hours & 19.3 & 7.0 & 36.3 \\
Third 24 hours & 5.8 & 1.4 & 24.1 \\
\hline
\end{tabular}

almost constant or increased a little during the same incubation period. The amount of hydrogen was very small. Fig. 2 shows the time courses measured at intervals of 8 hours. Time lag for hydrogen evolution (about 8 hours or more, but less than 16 hours) should be noted.

Effect of $\mathrm{pH}$ on hydrogen evolution from the cotyledon homogenates of Nelumbo seeds was examined. The optimum $\mathrm{pH}$ was about 7.2 (Fig. 3).

To examine the effect of light on hydrogen evolution, experiments on the Nelumbo seed and their homogenates with or without diffused daylight were performed. The results showed that light had no effect on the hydrogen evolution.

Effects of air on hydrogen evolution in homogenates of Nelumbo cotyledons are shown in Table 3. The amounts of the total gas and of hydrogen evolved in the presence of air during the first 24 hour period were less than those in the control without air. The effect of air became non-significant on the next day.

It is well known that oxygen inhibits the hydrogenase action. The results in Table 3 suggests the participation of hydrogenase in the mechanism of hydrogen production in Nelumbo seeds.

\section{References}

1) Toyoda, K., Bot. Mag. Tokyo $76: 41$ (1963).

2) Ormerod, J.G., Ormorod, K.S., and Gest, H., Arch. Biochem. Biophys. 94 : 449 (1961). 3) Ormerod, J. G., and Gest, H., Bacteriol. Rev. $26: 51$ (1962). 4) Gest, H., Ormerod, J. G., and Ormerod, K. S., Arch. Biochem. Biophys. 97 : 21 (1962). 5) Gaffron, H., and Rubin, J., J. Gen. Physiol. $26: 219$ (1942). 6) Gaffron, H., ibid. $26: 241$ (1942). 7) Frenkel, A.W., Arch. Biochem. Biophys. $38: 219$ (1952). 8) and Lewin, R. A., Amer. Jour. Bot. 41 : 586 (1954). 9) Spruit, C.T.P., Proc. 1st. Congr. Photobiol. 323 (1954). 10) - Mededel. Landbouwhogeschool Wageningen $58: 1$ (1958). 11) Damaschke, K., Z. Naturforschg. 12b: 441 (1957). 12) — und Lübke, M., ibid. 
13b: 54 (1958). 13) — und u, ibid. 13b: 134 (1958). 14) — — und , ibid. 13b: 172 (1958). 15) Frenkel, A. W., and Rieger, C., Nature 167: 1030 (1951).

16) Stephenson, M., and Stickland, S. L., Biochem. J. $25: 205$ (1931).

17) and , ibid. 25 : 215 (1931).

\section{摘要}

豊田清修：ハスと他の被子植物の種子に打ける水素の発生

1. 八スと他の数種の被子植物の発芽した種子のホモジェネートにおける水素の発生を研究した.

2. 水素の発生率は最初の 1 2 日間は, 非常に大きく, のち急減した.

3. 水素の発生率は空気によって抑制された，それはその機作にヒドロ ゲナーゼの関与することを示唆する.

4. 八ス子葉のホモジェネートにおける水素発生の至適 $\mathrm{pH}$ は 7.2 くらいにあった.

(神奈川蒾科大学生物学教室) 